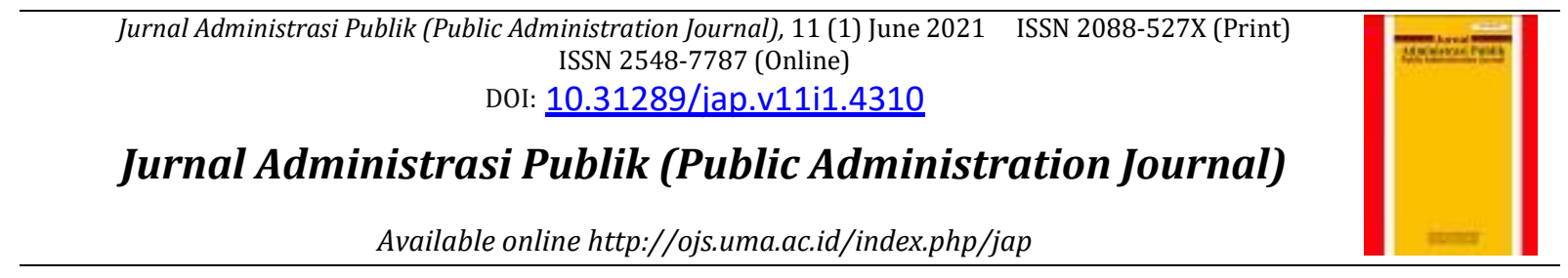

\title{
Blockchain Technology Immutability Framework Design in E-Government
}

\author{
Daelami Ahmad1), Ninda Lutfiani2)*, Alfian Dimas Ahsanul Rizki Ahmad3), \\ Untung Rahardja ${ }^{4)}$ \& Qurotul Aini ${ }^{4)}$
}

1) Commercial Administration Study Program, Sekolah Tinggi Ilmu Administrasi Banten, Indonesia

2) Master of Information Technology Department, Universitas Raharja, Indonesia

3) Science and Technology, Universitas Raharja, Indonesia

4) Faculty of Engineering, Doctor of Philosophy, UTM Johor Bahru, Malaysia

Received: 05 October 2020; Reviewed: 18 December 2020; Accepted: 21 February 2021

*corespoding author: ninda@raharia.info

\begin{abstract}
This study was conducted to determine the capacity of Blokchain technology in recording transactions that occurred in the ledger and in general it also offer the government to be applied to the e-Government sector which can increase data transparency, avoid fraud, and increase public trust in the government. This problem also focused on the application, challenges in the future with respect to the allocation of Blockchain technology, and in the e-Government sector, the use of Blockchain technology did not appear to be the main focus therefore it needed deeper observational evidence for the use of Blokchain technology. In its application, the biggest challenges in utilizing blockchain were generally presented as innovations such as security, scalability, and flexibility. In order to approach this problem, theoretical references were used from pre-existing studies that discuss Blokchain technology, e-Government, public services, and the data were collected through indexed journals both on a national and international scale. And the review of this paper concluded that academic research in this sector had only just begun and the issues addressed in the literature were still very limited. Therefore, more intensive research in this area is still needed to advance this field of research academic research in this sector had only just begun and the issues addressed in the literature are still very limited.
\end{abstract}

Keywords: Blokchain; E-Government; Public Services; Public Sector.

How to Cite: Ahmad, D., Lutfiani, N., Ahmad, A.D.A.R., \& Rahardja, U. (2021). Blockchain Technology Immutability Framework Design in E-Government. Jurnal Administrasi Publik (Public Administration Journal). 11 (1): 32-41. 


\section{INTRODUCTION}

Disruptive is an innovative theory initiated by new industrial players that threaten old players (Lutfiani, Harahap, et al., 2020). In current's digital era, the internet is growing very rapidly. Global internet users have reached 4.57 billion, $60 \%$ of the world's total population of 7,794 billion as of June 2020(Nisa 'et al., 2019; Rahardja et al., 2019). In terms of technological advances, we need a smart framework, which can help collaboration more effectively. Validity comes from the word validity which means the extent to which the accuracy and determination of a measuring instrument in carrying out its measurement function (Sudaryono et al., 2019; Sudaryono, Rochmawati, et al., 2020).

The framework should be strong enough to address governance across sectors such as organizations. Like POAC, the basic functions of POAC management have been widely applied in various sectors (Sudaryono, Rahardja, et al., 2020; Rahardja et al., 2020). Then making decisions based on the right data. Of course, the involvement of third parties can cost more. To solve this problem, various decentralized applications have been developed to allow peer-to-peer interaction between investors and developers (Hassija et al., 2020).

Over time, a new information technology innovation called Blokchain has emerged (Lutfiani, Oganda, et al., 2020). The emergence of Blokchain has paved the way for making peer-to-peer communication more open, fair, transparent, secure and cost-effective (Y. Hu et al., 2019; Puthal et al., 2014; Hassija et al., 2019).

Blockchain this was originally discovered around 1991 by the research team. In 2009 it was accepted by Satoshi Nakamoto to serve as Crypto Bitcoin currency. Blokchain is a new information technology innovation, disrupting services and industry, old institutional technology such as organization and corporate governance, markets, networks, and government (Berg et al., 2019).

At present, Blockchain technology is important, Blockchain can do many things, and there have been many technological innovations using Blockchain. Blokchain is a technology that can change the way markets and governments operate(Mesquita et al., 2020).

Blokchain technology has been considered the most innovative and most disruptive information technology of this century. It has been proven to be applicable in various areas beyond its first application, namely cryptocurrency, Bitcoin (Tshering \& Gao, 2020). Systematically, the Blockchain workflow is likened to a "big ledger" or "big ledger" system, digitally distributed, and each transaction is cryptographically signed which is then entered into blocks that are connected to one another (Tang et al., 2019).

In general, Blokchain has the following main characteristics (Z Zheng et al., 2017): Decentralization. Every transaction will be automatically validated and no third party will interfere. It can reduce errors, attacks from hackers, and transparency; Persintency, the recording mechanism in Blokchain technology, every record is impossible to change; Anonymity, with Blokchain technology, everyone who makes a transaction, the identity of that person will be disguised. In this way the user's privacy will be hidden and safe. Auditibility. All transactions will be stored sequentially so that they can be easily verified and tracked on the Blockchain.

In Eastern Europe, the governments have generally accepted Blokchain technology, and it has been used in various fields, such as registration in the justice system, health care system, security and others. 
Governments around the world are testing the potential use of Blokchain in their public sector, in particular, for property registrations and notary deeds (Konashevych \& Poblet, 2018). Dubai has implemented Blockchain technology in the public sector, by naming it FotoChain, the Dubai Government used Blockchain to reduce paper usage by digitally recording all important legal documents such as visas, bill payments, license renewals, etc.

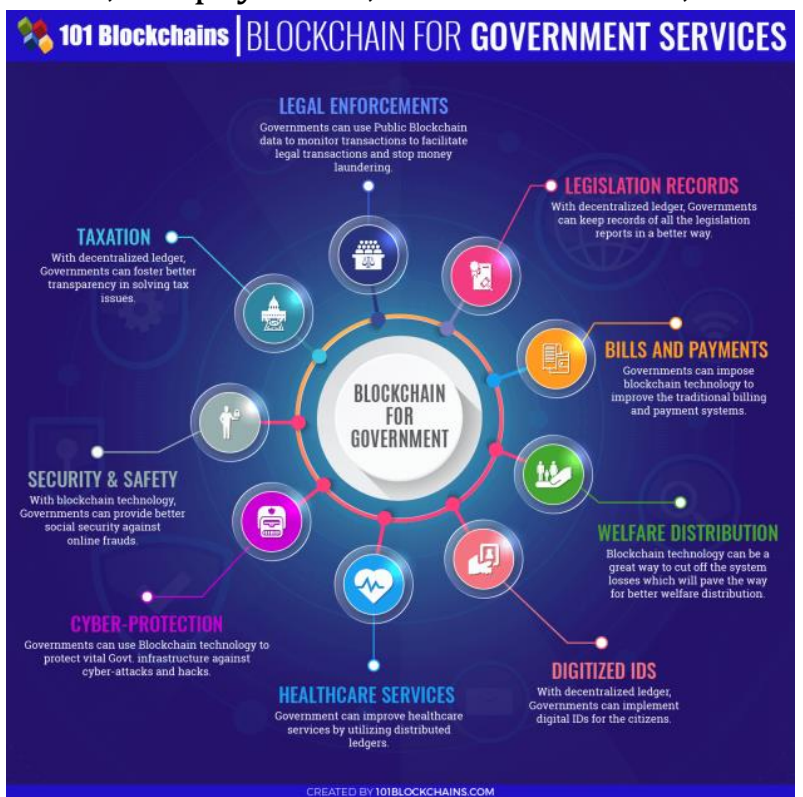

The use of Information Technology (IT) to improve the public sector is often called eGovernment (Batubara et al., 2019).

Figure 1. Blokchain For Government Service Source: 101Blokchains.com

At first Blockchain technology aimed to maintain existing technologies in the government (Batubara et al., 2019). The application of Blockhain technology aims to improve public services to the public and data security. Based on the principle of decentralization, where intermediaries or third parties can be eliminated, Smart Contracts are the key, will automatically transfer assets when the specified conditions are met (Queiroz et al., 2019).

Blokchain technology, which is the core of cryptocurrencies such as Bitcoin, Etherium, Vexanium, is a new innovation and has enormous potential for application in the public sector.
Blockchain has enormous potential for government, which makes work within the government more efficient in its application to public services and increases trust in the public sector (Konashevych, 2017). Not only it, the implementation of Blokchain can also be a big change in changing the way of recorded transactions.

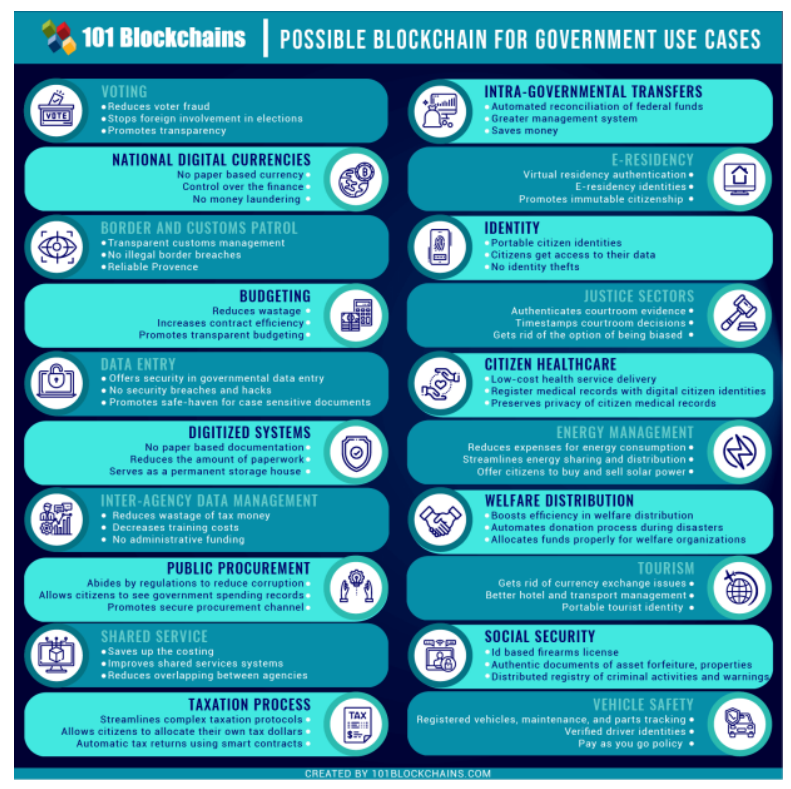

Figure 2. Use Cases Blokchain for Government Source: 101Blokchains.com

Governments around the world are starting to take advantage of the potential of Blokchain technology. Like Singapore, which has implemented Blockchain technology in the repair industry for interbank and cross currency payments. In India itself, precisely in the Maharashtra region, it planned to use Blockchain in motor vehicle registration, land registration, financial inclusion and Financial Supply Chain. (Batubara et al., 2018). It is strongly believed that Blokchain technology has enormous potential benefits for the government such as data integration, data security, data transparency, and privacy (Ølnes et al., 2017). In its application, Blockchain can eradicate corruption and increase transparency of financial data (Hyvärinen et al., 2017). Several countries such as the United States, United Kingdom, 
Netherlands, United Arab Emirates, Estonia, Sweden and China took the initiative to implement Blokchain technology in the public sector (Batubara et al., 2018). Some of the benefits that can be taken from Blokchain technology are transparency, thus increasing trust. It is especially useful for developing countries because developing countries are more prone to corruption and fraud than developed countries (Batubara et al., 2018). Currently there are still less studies that discuss the application of Blokchain technology in different sectors, most studies focus on cryptocurrencies such as bitcoin (Yli-Huumo et al., 2016).

With the literature review that we used for this study, we provide an overview of the application of Blokchain technology in the public sector as an illustration for practitioners who are interested in conducting studies on this theme.

Therefore, a literature review is used to map the challenges in applying Blokchain technology in the government sector. In the next section the methods we follow is presented to locate the literature.

\section{NON RESEARCH SYSTEMATICS}

The importance of Blokchain technology in the public sector, make we conducted a literature review to be able to identify the latest study and potential uses of Blokchain technology in e-Government applications. To achieve it, we formulated several research questions. What are the challenges that must be faced in implementing Blokchain technology in eGovernment applications?

In this paper, we used guidelines for systematic literature review, and used search terms such as "Blokchain" "Block Chain" "Government" "Public Service" "Public Sector". We used three journal sources to find research articles: Scopus, ScienceDirect, SpringerLink, and Emerald. Titles, abstracts and keywords were used to search for published journal papers, conference proceedings, workshops, and symposia.

Table 1. Advantages \& Disadvantages of Blokchain Technology according to Characteristics

\begin{tabular}{|c|c|c|}
\hline $\begin{array}{l}\text { Blokchain } \\
\text { characteristics }\end{array}$ & Advantages & Disadvantages \\
\hline $\mathrm{P}_{2} \mathrm{P}$ & $\begin{array}{l}\mathrm{P}_{2} \mathrm{P} \text { transactions are possible without } \\
\text { a third service provider. }\end{array}$ & $\begin{array}{l}\text { When problems arise, it is uncertain who is } \\
\text { responsible }\end{array}$ \\
\hline Scalability & $\begin{array}{l}\text { Easy to create, connect and expand by } \\
\text { disclosed sources. reduced system } \\
\text { development costs. }\end{array}$ & $\begin{array}{l}\text { The number of transactions that allow } \\
\text { payments to be handled is very small } \\
\text { compared to the scale of transactions in the } \\
\text { real economy }\end{array}$ \\
\hline Transparency & $\begin{array}{l}\text { All Transaction Records can be } \\
\text { accessed by the public. Legalization of } \\
\text { transactions and reduction of } \\
\text { regulatory fees. }\end{array}$ & $\begin{array}{l}\text { As transaction details are disclosed, all } \\
\text { transactions are traceable. In principle, } \\
\text { perfect guarantees for pseudo anonymity } \\
\text { may be difficult and re-identification by } \\
\text { combining them is possible }\end{array}$ \\
\hline Security & Ledger jointly owned (integrity) & $\begin{array}{l}\text { When a private key is hacked or lost, there is } \\
\text { no general solution }\end{array}$ \\
\hline $\begin{array}{l}\text { System } \\
\text { stability }\end{array}$ & $\begin{array}{l}\text { There is not a single point of failure } \\
\text { If errors or impairments occur in a } \\
\text { particular participant system, the } \\
\text { effect on the entire network is very } \\
\text { small }\end{array}$ & $\begin{array}{l}\text { Excavation focuses on large mining pools. } \\
\text { It's hard to run large volume handling in real } \\
\text { time. }\end{array}$ \\
\hline
\end{tabular}

Source: (Oh \& Shong, 2017). 


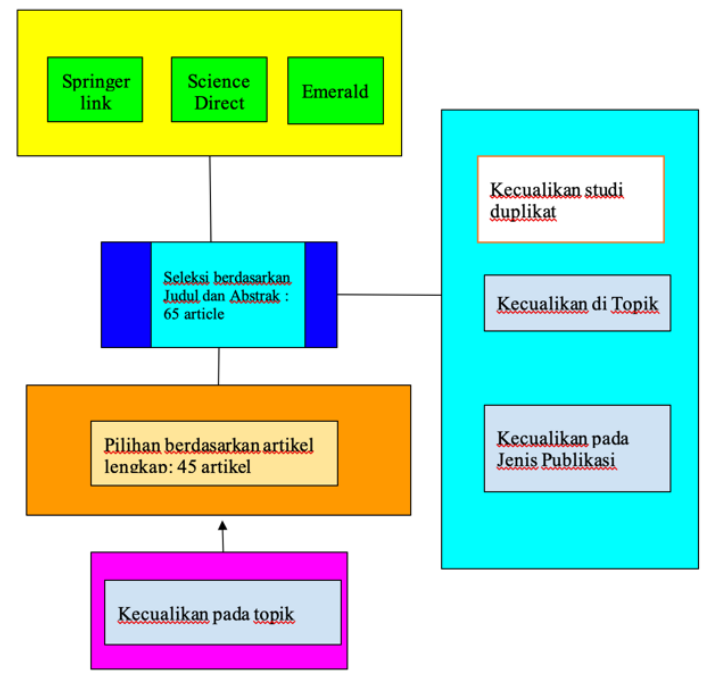

Figure 3. Article Writing workflow Source: Author

A number of additional criteria that have been determined for selecting a suitable study to be included in the literacy review must have several points, one of them is to be published in a reputable journal, then to present research on the implementation of Blokchain technology in the eGovernment sector, and not to duplicate articles from other sources. The following are the criteria for scientific articles that we will be entered.

Eligible articles were manually read to check the relevance of our literature review. Evaluations based on full text reading reduced the number of articles to a number of articles.

Furthermore, we analyzed the data using qualitative analysis methods on several papers that have been collected, then we conducted an analysis by looking at the year of publication, type of publication, stages of the research process, and the problems mentioned in the selected articles.
Next we presented a description of the selected articles and analyzed them in order to discover the challenges they present in the implementation of Blokchain technology in the eGovernment sector.

\section{RESULTS AND DISCUSSION}

In this section, the author presented the results of a literature review, presented a descriptive overview of the selected articles, then presented the challenges found in the selected articles.

Most of the research when discussing the implementation of Blockchain Technology to be applied to government / e-Government generally discusses ideas, potential benefits, current issues, potential uses (Kung et al., 2020; Hou, 2017 Margheri et al., 2017; Ølnes, 2016; Ølnes et al., 2017; Ølnes \& Jansen, 2017). Then the application of Blockchain technology in the health sector was usually applied in the patient's medical track record(Tandon et al., 2020; Kung et al., 2020; Oflaz, 2019; Roehrs et al., 2019). Blokchain technology can create a secure and flexible ecosystem for exchanging electronic health records (EHRs/Electronic Health Records). This technology could also make Healthcare clearer by creating origins for organs, blood, critical medicine, etc. And also by storing all medical licenses/certificates in Blokchain, fraudulent doctor practices could be prevented. In addition, Blockchain could be applied in the education sector, then it could store such as education certificates, student data, faculty data, etc., is an important part that is played in the education sector. The origin of these certificates, data, and so on also needed to be concluded properly. 
Table. 2 Blockchain Technology References

\begin{tabular}{lll}
\hline No. & Context & Reference \\
\hline $\mathbf{1}$ & E-Government & $\begin{array}{l}\text { (Kung et al., 2020) (Hou, 2017) (Margheri et al., 2017) (Ølnes, 2016) (Ølnes et } \\
\text { al., 2017) (Ølnes \& Jansen, 2017) }\end{array}$ \\
\hline $\mathbf{2}$ & Health & (Tandon et al., 2020) (Kung et al., 2020) (Oflaz, 2019)(Roehrs et al., 2019) \\
\hline $\mathbf{3}$ & Education & $\begin{array}{l}\text { (Suyambu et al., 2020) (Yumna et al., 2019) (Guo et al., 2020) (Chen et al., } \\
\text { 2018) }\end{array}$ \\
\hline $\mathbf{4}$ & Finance & $\begin{array}{l}\text { (George et al., 2019) (Ahluwalia et al., 2020) (Swan, 2019) (W. Hu \& Huanhao, } \\
\text { 2020) (Liang et al., 2020) (Xiao et al., 2020) (Xue \& Lu, 2020) }\end{array}$ \\
\hline $\mathbf{5}$ & Smart City & $\begin{array}{l}\text { smart city context (Bhushan et al., 2020) (Brandão et al., 2019) (Fan et al., } \\
\text { 2020) (Iftikhar et al., 2020) (Orecchini et al., 2019) }\end{array}$ \\
\hline $\mathbf{6}$ & Digital Identity & (Sullivan \& Burger, 2017) \\
\hline $\mathbf{7}$ & E-Voting & (Moura \& Gomes, 2017) \\
\hline $\mathbf{8}$ & Tax & $\begin{array}{l}\text { (Wijaya et al., 2017), (Choi \& Luo, 2019) (Hossain et al., 2020) (Wang, 2020) } \\
\text { (Yalaman \& Y1ldırı, 2019) }\end{array}$ \\
\hline
\end{tabular}

Source: Analysis paper results

From table 2, we can see some written literature that discusses Blockchain technology in various sectors. The education and financial sectors are the sectors most observed and researched by researchers, however in the eGovernment sector it is still very limited. Apart from the education and financial sectors, the researchers also discussed the Smart city sector, digital identity, eVoting, and taxes. For example, in controlling the increase in cigarette consumption, the Indonesian government relied heavily on increasing excise and taxes on tobacco products (Nuvrianto, 2020).

The application of Blockchain technology can provide benefits, especially in the aspects of security, data transparency, and building public trust. The public service sector could be applied blockchain technology such as in taxation, for example in controlling and controlling the increase in cigarette consumption, the Indonesian government relied a lot on increasing excise and taxes on tobacco products (Nuvrianto, 2020), where with Blockchain technology could provide real time information, the tax payment process that did not require a lot of time and level can increase the level of transparency. Furthermore, on the other hand, the application of blockchain technology in other public services was in the context of digital identity, where Blockchain provided guarantees for the security of personal data.

In addition, the development of the application of blockchain technology in the e-government sector required a large amount of funding, so that readiness was needed in terms of human resources and society. There are several advantages that can be obtained when implementing blockchain technology in the eGovernment sector.

\section{CONCLUSION}

Based on the results of the research and discussion that has been carried out, it can be understood thoroughly regarding the use of Blockchain technology in the eGovernment sector. We have found that academic research in this sector has only just begun and that the issues addressed in the literature are very limited. Although there were already several countries that have implemented Blockchain technology in the e-Government sector, such as Dubai which used Blockchain to reduce paper usage by digitally recording all important legal documents. Therefore, more intensive research is needed in this field. In particular, empirical studies are needed, using rigorous research measures 
to be applied in the context of the eGovernment sector.

\section{BIBLIOGRAPHY}

Ahluwalia, S., Mahto, R. V, \& Guerrero, M. (2020). Blokchain technology and startup financing: A transaction cost economics perspective. Technological Forecasting and Social Change, 151, 119854. https://doi.org/https://doi.org/10.1016/j. techfore.2019.119854

Batubara, F. R., Ubacht, J., \& Janssen, M. (2018). Challenges of Blokchain technology adoption for e-government: a systematic literature review. Proceedings of the 19th Annual International Conference on Digital Government Research: Governance in the Data Age, 1-9.

Berg, C., Davidson, S., \& Potts, J. (2019). Capitalism after Satoshi: Blokchains, dehierarchicalisation, innovation policy, and the regulatory state. Journal of Entrepreneurship and Public Policy, 9(2), 152-164. https://doi.org/10.1108/JEPP03-2019-0012

Bhushan, B., Khamparia, A., Sagayam, K. M., Sharma, S. K., Ahad, M. A., \& Debnath, N. C. (2020). Blokchain for smart cities: A review of architectures, integration trends and future research directions. Sustainable Cities and Society, 61, 102360. https://doi.org/https://doi.org/10.1016/j. scs.2020.102360

Brandão, A., Mamede, H. S., \& Gonçalves, R. (2019). A Smart City's Model Secured by Blokchain $B T$ - Trends and Applications in Software Engineering (J. Mejia, M. Muñoz, Á. Rocha, A. Peña, \& M. Pérez-Cisneros (eds.); pp. 249260). Springer International Publishing.

Chen, G., Xu, B., Lu, M., \& Chen, N.-S. (2018). Exploring Blokchain technology and its potential applications for education. Smart Learning Environments, 5(1), 1. https://doi.org/10.1186/s40561-0170050-x

Choi, T.-M., \& Luo, S. (2019). Data quality challenges for sustainable fashion supply chain operations in emerging markets: Roles of Blokchain, government sponsors and environment taxes. Transportation Research Part E: Logistics and Transportation Review, 131, 139-152. https://doi.org/https://doi.org/10.1016/j. tre.2019.09.019

Fan, L., Cronemberger, F., \& Gil-Garcia, J. R. (2020). Using Blokchain Technology to Manage IoT Data for Smart City Initiatives: A Conceptual Framework and Initial Experiments Based on Smart Contracts BT - Beyond Smart and
Connected Governments: Sensors and the Internet of Things in the Public Sector (J. R. Gil-Garcia, T. A. Pardo, \& M. GascoHernandez (eds.); pp. 85-108). Springer International Publishing. https://doi.org/10.1007/978-3-03037464-8_5

George, R. P., Peterson, B. L., Yaros, O., Beam, D. L., Dibbell, J. M., \& Moore, R. C. (2019). Blokchain for business. Journal of Investment Compliance, 20(1), 17-21. https://doi.org/10.1108/joic-01-20190001

Guo, J., Li, C., Zhang, G., Sun, Y., \& Bie, R. (2020). Blokchain-enabled digital rights management for multimedia resources of online education. Multimedia Tools and Applications, 79(15), 9735-9755. https://doi.org/10.1007/s11042-01908059-1

Hassija, V., Bansal, G., Chamola, V., Saxena, V., \& Sikdar, B. (2019). BlockCom: A Blokchain based commerce model for smart communities using auction mechanism. 2019 IEEE International Conference on Communications Workshops, ICC Workshops 2019 - Proceedings, 1-6. https://doi.org/10.1109/ICCW.2019.8756 808

Hassija, V., Chamola, V., \& Zeadally, S. (2020). BitFund: A Blokchain-based crowd funding platform for future smart and connected nation. Sustainable Cities and Society, 60, 102145. https://doi.org/10.1016/j.scs.2020.10214 5

Hossain, S., Saha, S., Akhi, J. F., \& Helaly, T. (2020). Automated Tax Return Verification with Blokchain Technology BT - Proceedings of International Joint Conference on Computational Intelligence (M. S. Uddin \& J. C. Bansal (eds.); pp. 45-55). Springer Singapore.

Hou, H. (2017). The application of Blokchain technology in E-government in China. 2017 26th International Conference on Computer Communication and Networks (ICCCN), 1-4.

Hu, W., \& Huanhao, L. (2020). A Direct Transaction Model for Energy Blokchain Mobile Information System Based on Hybrid Quotation Strategy BT - Design, Operation and Evaluation of Mobile Communications (G. Salvendy \& J. Wei (eds.); pp. 33-51). Springer International Publishing.

$\mathrm{Hu}, \mathrm{Y} .$, Manzoor, A., Ekparinya, P., Liyanage, M., Thilakarathna, K., Jourjon, G., \& Seneviratne, A. (2019). A Delay-Tolerant payment scheme based on the ethereum Blokchain. IEEE Access, 7, 33159-33172. 
https://doi.org/10.1109/ACCESS.2019.29 03271

Hyvärinen, H., Risius, M., \& Friis, G. (2017). A Blokchain-based approach towards overcoming financial fraud in public sector services. Business \& Information Systems Engineering, 59(6), 441-456.

Iftikhar, M. Z., Iftikhar, M. S., Jawad, M., Chand, A., Khan, Z., Khan, A. B. M., \& Javaid, N. (2020). Efficient Resource Utilization Using Blokchain Network for IoT Devices in Smart City BT - Advances on Broad-Band Wireless Computing, Communication and Applications (L. Barolli, P. Hellinckx, \& T. Enokido (eds.); pp. 521-534). Springer International Publishing.

Konashevych, O. (2017). The concept of the Blokchain-based governing: Current issues and general vision. Proceedings of the European Conference on E-Government, ECEG, 79-85.

Konashevych, O., \& Poblet, M. (2018). Is Blokchain hashing an effective method for electronic governance? Frontiers in Artificial Intelligence and Applications, 313, 195-199. https://doi.org/10.3233/978-1-61499935-5-195

Kung, H. H., Cheng, Y.-F., Lee, H.-A., \& Hsu, C.-Y. (2020). Personal Health Record in FHIR Format Based on Blokchain Architecture BT - Frontier Computing (J. C. Hung, N. Y. Yen, \& J.-W. Chang (eds.); pp. 1776-1788). Springer Singapore.

Liang, W., Lei, X., Li, K.-C., Fan, Y., \& Cai, J. (2020). A Dual-Chain Digital Copyright Registration and Transaction System Based on Blokchain Technology BT - Blokchain and Trustworthy Systems (Zibin Zheng, H.-N. Dai, M. Tang, \& X. Chen (eds.); pp. 702-714). Springer Singapore.

Lutfiani, N., Harahap, E. P., Aini, Q., Ahmad, A. D. A. R., \& Rahardja, U. (2020). Inovasi Manajemen Proyek I-Learning Menggunakan Metode Agile Scrumban. InfoTekJar: Jurnal Nasional Informatika Dan Teknologi Jaringan, 5(1).

Lutfiani, N., Oganda, F. P., Lukita, C., Aini, Q., \& Rahardja, U. (2020). Desain dan Metodologi Teknologi Blokchain Untuk Monitoring Manajemen Rantai Pasokan Makanan yang Terdesentralisasi. InfoTekJar: Jurnal Nasional Informatika Dan Teknologi Jaringan, 5(1).

Margheri, A., Ferdous, M. S., Yang, M., \& Sassone, V. (2017). A distributed infrastructure for democratic cloud federations. 2017 IEEE 10th International Conference on Cloud Computing (CLOUD), 688-691.
Mesquita, L. A. F., Pozzebon, M., \& Petrini, M. (2020). Blokchain and a Technological Perspective for Public Administration: A Systematic Review. Journal of Contemporary Administration, 25(1), 181-196.

Moura, T., \& Gomes, A. (2017). Blokchain voting and its effects on election transparency and voter confidence. Proceedings of the 18th Annual International Conference on Digital Government Research, 574-575.

Nisa', K., Rusfian, E., \& Zaenab, Z. (2019). Managing Government Digital Reputation through Big Data Processing. JKAP (Jurnal Kebijakan Dan Administrasi Publik), 22(2), 72. https://doi.org/10.22146/jkap.31810

Nuvrianto, M. N. (2020). Government Challenges in Simplifying Tobacco Excise Rate Structure to Minimize Cigarette Manufacturer Excise tax Avoidance in Indonesia. 24(1), 43-60.

Oflaz, N. K. (2019). Using Smart Contracts via Blokchain Technology for Effective Cost Management in Health Services BT Blokchain Economics and Financial Market Innovation: Financial Innovations in the Digital Age (U. Hacioglu (ed.); pp. 423-449). Springer International Publishing. https://doi.org/10.1007/978-3-03025275-5_21

Ølnes, S. (2016). Beyond bitcoin enabling smart government using Blokchain technology. International Conference on Electronic Government, 253-264.

Ølnes, S., \& Jansen, A. (2017). Blokchain technology as $\mathrm{s}$ support infrastructure in egovernment. International Conference on Electronic Government, 215-227.

Ølnes, S., Ubacht, J., \& Janssen, M. (2017). Blokchain in government: Benefits and implications of distributed ledger technology for information sharing. Elsevier.

Orecchini, F., Santiangeli, A., Zuccari, F., Pieroni, A., \& Suppa, T. (2019). Blokchain Technology in Smart City: A New Opportunity for Smart Environment and Smart Mobility BT Intelligent Computing \& Optimization (P. Vasant, I. Zelinka, \& G.-W. Weber (eds.); pp. 346-354). Springer International Publishing.

Puthal, D., Malik, N., Mohanty, S. P., Kougianos, E., \& Yang, C. (2014). The Blokchain as a Decentralized Security Framework. IEEE Consumer Electronics Magazine, 11, 17-19.

Queiroz, M. M., Telles, R., \& Bonilla, S. H. (2019). Blokchain and supply chain management integration: a systematic review of the literature. Supply Chain Management, 25(2), 241-254. https://doi.org/10.1108/SCM03-2018-0143 
Rahardja, U, Lutfiani, N., Rafika, A. S., \& Harahap, E. P. (2020). Determinants of Lecturer Performance to Enhance Accreditation in Higher Education. 2020 8th International Conference on Cyber and IT Service Management (CITSM), 1-7. https://doi.org/10.1109/CITSM50537.202 0.9268871

Rahardja, Untung, Lutfiani, N., \& Amelia, S. (2019). Creative Content Marketing In Scientific Publication Management In Industrial Era 4.0. Aptisi Transactions on Management (ATM), 3(2), 168-178. https://doi.org/10.33050/atm.v3i2.991

Rizal Batubara, F., Ubacht, J., \& Janssen, M. (2019). Unraveling Transparency and Accountability in Blokchain. Proceedings of the 20th Annual International Conference on Digital Government Research, 204-213.

Roehrs, A., da Costa, C. A., da Rosa Righi, R., da Silva, V. F., Goldim, J. R., \& Schmidt, D. C. (2019). Analyzing the performance of a Blokchainbased personal health record implementation. Journal of Biomedical Informatics, $\quad 92, \quad 103140$. https://doi.org/https://doi.org/10.1016/j. jbi.2019.103140

Sudaryono, Rahardja, U., Aini, Q., Isma Graha, Y., \& Lutfiani, N. (2019). Validity of Test Instruments. Journal of Physics: Conference Series, 1364(1). https://doi.org/10.1088/17426596/1364/1/012050

Sudaryono, Rahardja, U., \& Lutfiani, N. (2020). The Strategy of Improving Project Management Using Indicator Measurement Factor Analysis (IMF) Method. Journal of Physics: Conference Series, 1477(3). https://doi.org/10.1088/17426596/1477/3/032023

Sudaryono, S., Rochmawati, R., Lutfiani, N., \& Rahardja, U. (2020). Strategy Enhancing Employee Reward Using the TOPSIS Method as a Decision Support System. IJCCS (Indonesian Journal of Computing and Cybernetics Systems), 14(4), 387-396.

Sullivan, C., \& Burger, E. (2017). E-residency and Blokchain. Computer Law \& Security Review, 33(4), 470-481. https://doi.org/https://doi.org/10.1016/j. clsr.2017.03.016

Suyambu, G. T., Anand, M., \& Janakirani, M. (2020). Blokchain - A Most Disruptive Technology On The Spotlight of World Engineering Education Paradigm. Procedia Computer Science, 172, 152-158. https://doi.org/https://doi.org/10.1016/j. procs.2020.05.023
Swan, M. (2019). Blokchain Economic Networks: Economic Network Theory-Systemic Risk and Blokchain Technology BT - Business Transformation through Blokchain: Volume I (H. Treiblmaier \& R. Beck (eds.); pp. 3-45). Springer International Publishing. https://doi.org/10.1007/978-3-31998911-2_1

Tandon, A., Dhir, A., Islam, A. K. M. N., \& Mäntymäki, M. (2020). Blokchain in healthcare: A systematic literature review, synthesizing framework and future research agenda. Computers in Industry, 122, 103290. https://doi.org/https://doi.org/10.1016/j. compind.2020.103290

Tang, Y., Xiong, J., Becerril-Arreola, R., \& Iyer, L. (2019). Ethics of Blokchain: A framework of technology, applications, impacts, and research directions. Information Technology and People, 33(2), 602-632. https://doi.org/10.1108/ITP-10-20180491

Tshering, G., \& Gao, S. (2020). Understanding security in the government's use of Blokchain technology with value focused thinking approach. Journal of Enterprise Information Management, 33(3), 519-540. https://doi.org/10.1108/JEIM-06-20180138

Wang, J. (2020). Application of Blokchain Technology in Tax Collection and Management BT - Cyber Security Intelligence and Analytics (Z. Xu, R. M. Parizi, M. Hammoudeh, \& O. Loyola-González (eds.); pp. 50-58). Springer International Publishing.

Wijaya, D. A., Liu, J. K., Suwarsono, D. A., \& Zhang, P. (2017). A New Blokchain-Based ValueAdded Tax System BT - Provable Security (T. Okamoto, Y. Yu, M. H. Au, \& Y. Li (eds.); pp. 471-486). Springer International Publishing.

Xiao, L., Deng, H., Tan, M., \& Xiao, W. (2020). Insurance Block: A Blokchain Credit Transaction Authentication Scheme Based on Homomorphic Encryption BT - Blokchain and Trustworthy Systems (Zibin Zheng, H.-N. Dai, M. Tang, \& X. Chen (eds.); pp. 747-751). Springer Singapore.

Xue, F., \& Lu, W. (2020). A semantic differential transaction approach to minimizing information redundancy for BIM and Blokchain integration. Automation in Construction, 118, 103270. https://doi.org/https://doi.org/10.1016/j. autcon.2020.103270

Yalaman, G. Ö., \& Yıldırım, H. (2019). Cryptocurrency and Tax Regulation: Global Challenges for Tax Administration BT - 
Blokchain Economics and Financial Market Innovation: Financial Innovations in the Digital Age (U. Hacioglu (ed.); pp. 407-422). Springer International Publishing. https://doi.org/10.1007/978-3-03025275-5_20

Yli-Huumo, J., Ko, D., Choi, S., Park, S., \& Smolander, $\mathrm{K}$. (2016). Where is current research on Blokchain technology? - A systematic review. PLoS ONE, 11(10), 1-27. https://doi.org/10.1371/journal.pone.016 3477
Yumna, H., Khan, M. M., Ikram, M., \& Ilyas, S. (2019). Use of Blokchain in Education: $A$ Systematic Literature Review BT - Intelligent Information and Database Systems (N. T. Nguyen, F. L. Gaol, T.-P. Hong, \& B. Trawiński (eds.); pp. 191-202). Springer International Publishing.

Zheng, Z, Xie, S., Dai, H., Chen, X., \& Wang, H. (2017). An Overview of Blokchain Technology: Architecture, Consensus, and Future Trends. 2017 IEEE International Congress on Big Data (BigData Congress), 557-564. 